\title{
The Phrase "The Great War" in British Discourse during World War One
}

The First World War retains a profound hold over the contemporary consciousness. In Britain those who fought for the country in all wars are still remembered on the anniversary of Armistice Day in 1918, while one web-site lists over 200 books in English published in the past five years about the conflict which include "the Great War" in the title (Amazon 2015).

The fact that the phrase "the Great War" still has currency in reference to a century-old experience, and after all of the wars that have happened since, implies the degree to which its impact is still felt, and also the possibility that if its "greatness" ever meant it was a glorious enterprise, it no longer applies. However, the notion that British political leaders used the phrase liberally in the hope of winning a propaganda and recruiting victory 100 years ago would not be accurate, and instead a brief survey of its use (and non-use) at that time provides a revealing image in which some of the most powerful political and media figures often acted with public trepidation, while those who overtly promoted war against Germany were relatively marginal. I include a relatively full examination of opinions expressed in Punch magazine because I believe its attempts to appeal to a conservative, well-healed, distinctly nonintellectual readership, a constant pursuit of current conformity, offer a good guide to "respectable" views of the time. ${ }^{1}$

The Oxford English Dictionary records the first use of the phrase about the 1914-1918 war as being in a Canadian publication, Maclean's Magazine, in October $1914,{ }^{2}$ in an article about the nascent conflict: "Some wars name themselves ... This is the great war" (Simpson 1991, 703). Other accounts, such as Patricia Treble's (2014), accept this as the earliest known use about the First World War. Earlier campaigns had been given the description, so that the Napoleonic Wars, for example in the 1911 book British Statesmen of the Great War: 17931814 and Narratives in Some Passages from the Great War with France, from 1799 to 1810, from 1854, were thought to have been "great", plausibly both to signify how momentous it was and that "we" (Napoleon's opponents) won.

Judging by the later of the two above-mentioned publications, for a hundred years right until the start of World War One, in Britain "the Great War" had meant the series of battles against

${ }^{1}$ Esther MacCallum-Stewart has written an interesting analysis of the magazine, including that the editor, Owen Seaman, frequently had to guess whether or not his readers' opinions had changed:

For this reason, Punch is a dominant text in our understanding of the war, exemplifying and misinterpreting public sentiment from a civilian viewpoint. When the war began, Punch was violently pro-war, articles and cartoons often recounting little more than propaganda with very little comedic undertones. However, this attitude discreetly wanes as the war dragged on and the civilian population became increasingly discontented and disillusioned. It was impossible to ignore the effects the fighting was starting to have, and as Punch moves into the latter stages of 1917-18, this awareness becomes gradually visible (MacCallum-Stewart 2009).

I have chosen to refer to the month and year a quotation appeared in Punch rather than the volume number because I think it is often relevant at which point in the war it was published.

${ }^{2}$ However, as seen below, there were earlier examples. 
Napoleon Bonaparte's army and navy. With the outbreak of a new multinational conflict, and with Britain as one of the first nations to be declared as a combatant, the manner in which some politicians who had led their population to war and would be responsible for its conduct, used the phrase in public communication revealed a definite lack of confidence in the public's enthusiasm and support. Instead of the "greatness" being symbolic of the glorious enterprise and post-bellum future to which their voters might aspire, it was an apologia for the more or less terrible sacrifice the situation demanded.

Herbert Henry Asquith ${ }^{3}$ was the British prime-minister from 1908-1916 and the Secretary of State for War from March-August 1914 (Taylor, 1992, 3). His task was to persuade his fellow parliamentarians and the British public that the only viable option in the summer of 1914 was to go to war with Germany. Publicly he was at pains to show that, while he considered his decision unavoidable, he did so with a sense of anguish: "with the utmost reluctance and with infinite regret, His Majesty's Government have been compelled to put this country in a state of war" (Speeches 1914-1916, August $6^{\text {th }} 1914,3$ ). In the same speech he announced that he could not continue to hold two positions, and Lord Kitchener had agreed to oversee the War ministry, as it would not be right for Asquith to only give "perfunctory attention to the affairs of our Army in a great war" (10). He was eager to blame Germany, for which the evidence was "patent, manifold and overwhelming", through hyperbole instead of evidence, and accepting German culpability meant that it was very different to "the great wars of history [which] have been almost accidentally brought on" (September $25^{\text {th }} 1914,37$ ).

It is conspicuous how Asquith generally chose to describe the First World War as "the Great War" at an implicit level, as though he dared not appear to be enjoying the experience. When justifying the money needed for the campaign, he made comparison to "our expenditure upon the great wars of the past" starting with "the Great War" of 1793-1815 (March $1^{\text {st }} 1915,63$ ). He went from naming the war by syllogism-he was explaining the monetary demands of that war by citing other "great" wars as precedents, therefore the war then being fought was "great"-to being, eight months later, more direct: "This War, like all the great wars of history, has been fruitful in surprises and disappointments" (November $2^{\text {nd }} 1915,73$ ). Asquith's suggestive use of "great war" served a few purposes. By referring to previous examples he was able to claim that the contemporaneous ordeals were not unique and that, with the prime example a century before, a war lasting over twenty years had ultimately been successful for Britain and her allies; while framing the present war in terms of the costs (human and financial) of earlier confrontations meant he avoided the ambiguity of the word "great", stating that it would be of pervasive consequence without calling it wonderful.

The rhetorical use of the phrase when pleading to the country-"we cannot sustain the burden which this great War has laid upon us unless ... [we] are prepared to make, far greater sacrifices than we have hitherto done" (92)-may well have had, at best, only short term

\footnotetext{
${ }^{3}$ Herbert Henry Asquith, first earl of Oxford and Asquith (1852-1928), was awarded first class honours in literae humaniores at Balliol College Oxford, he married Helen Melland in 1877, became the Liberal M.P. for East Fife in 1886, his wife died of typhoid in 1891, he was home secretary from 1892-1895, married Margot Tennant in 1894, was chancellor of the exchequer from 1905-1908, primeminister from 1908-1916 (initially, at least, seen as a progressive, with Lloyd George as chancellor, though the war prevented, for example, reform of the House of Lords), and he accepted an earldom from the king in 1925 (Matthew 2004).
} 
success. According to a record of his war speeches, in the five he made in 1916 (his last year as prime-minister), he never once said "the great war" (104-140). It is possible he feared it could be seen as metonymy for a political con-trick, and even a clue to his own duplicity, which he revealed in private correspondence. Amongst other young women of personal interest, Asquith became particularly attached to Venetia Stanley and wrote hundreds of letters to her while he was prime-minister. The notion of him detailing government secrets during cabinet meetings (Taylor 1992, 3) was then profoundly worrying to Winston Churchill-the letters were "England's greatest security risk" (Manchester 1983, 557)-and now are invaluable for the insight they provide. In contrast to his public regret at the unfortunate need for sacrifices on a grand scale, Asquith wrote to the young lady that "'the sudden outburst of the Great War"' had been the luckiest break of his career (Brock 1992,111). He was less assiduous with other correspondents. Three of his sons volunteered for the front line and wrote to their father about their experiences, but it is believed that he never replied (Mosley 2002).

Asquith's successor had a markedly different attitude as prime-minister, both to his predecessor and to himself in the first half of the war. At the outbreak of war Lloyd George ${ }^{4}$ was unequivocal about Britain's obligation to fight: "The stern hand of fate has scourged us to an elevation where we can see the great everlasting things which matter for a nation - the great peaks we had forgotten, of Honour, Duty, Patriotism, and clad in glittering white, the great pinnacle of Sacrifice pointing like a rugged finger to Heaven" (Speeches September $19^{\text {th }} 1914$, 225). In three, admittedly lengthy, speeches, two from 1914 and one from the end of 1916 when he had become prime-minister, the phrase "great war" was spoken nine times, to name the moral imperative of crushing a pernicious enemy, and in terms of what he saw as the inevitable costs of this scale of conflict. It was "a great War for the emancipation of Europe from the thraldom of a military caste ... now plunging the world into a welter of bloodshed and death" (224), and though "this great War had been forced by the Prussian military leaders" on Europe, to fail to stand up to "this swashbuckling through the streets of Europe to the disturbance of all harmless and peaceful citizens" would be foolish (Speeches December 19 $\left.9^{\text {th }} 1916,252\right)$.

When speaking before 1917 of the necessary commitments and sacrifices Lloyd George adopted a pragmatic approach. In December 1916 he proposed the nationalization of shipbuilding because of the maritime losses, "inevitable in any great war, especially when you are dealing with such piratical methods" as the Germans use (262). In the same speech when he referred to people it was as if they were material resources. To ensure "the success of this country in this great War" required "the mobilization of the labour reserves of the country" (267). By 1917 Lloyd George appears to have undergone a painful transformation, such that the phrase "the great war" would no longer be congruent.

${ }^{4}$ David Lloyd George, first Earl Lloyd-George of Dwyfor (1863-1945), was brought up under a strong Liberal influence, he qualified with honours for the Law Society in 1884, by 1886 he had a reputation as a brilliant speaker and had wavered over Irish Home rule (whether or not to support Gladstone). He became M. P. for Caernafon Boroughs in 1890, fiercely opposed the Boer War at considerable personal risk, became chancellor in 1908, introduced the Welfare State (National Insurance Act) in 1911, was minister of munitions from 1915-1916 then secretary of state for war for a few months, and prime-minister from 1916-1922 when he publicly clashed with his generals. In his seventies he took to fruit farming in Surrey, but remained an M. P. until 1945, when he received an earldom (Morgan 2004). 
In September 1914 he had said that nobody anticipated "engaging in a great war with greater reluctance . . . than I have done ... There is no man . . . more convinced we could not have avoided it without national dishonour" (Speeches 211). As far as we can now ascertain, this statement was a sincere representation of his views. At the start of August 1914 he had argued in the cabinet for peace, but once he judged "events too strong for him" he became wholly committed to war (Wilson 10). However, it is also true that as an astute politician Lloyd George was eager to know of the popular will and in this cause he maintained close contacts with at least five newspaper editors (Taylor 28). After a few months as prime-minister his remorse became evident, though he is thought to have been concerned about ill-conceived military planning and the resulting pointless and enormous casualty figures from early 1915 (Morgan 2004). In the House of Commons (June 11 ${ }^{\text {th }}$ 1917), speaking in tribute to a Major Redmond, he lamented "the sacrifices imposed upon these islands by this terrible War" (Hansard). Following a dinner in December 1917 with a war correspondent, Philip Gibbs, Lloyd George spoke to C. P. Scott, editor of the Manchester Guardian, about the terrible truth of the war and what the people "don't know, and can't know." In combination, the censors and newspapers give "a pretty picture of the war with everybody doing gallant deeds. The thing is horrible and beyond human nature to bear and I feel I can't go on with this bloody business" (Wilson 1970, 274) There are several possible reasons for his despondency-that he was hearing more details from the front, that he felt more personally responsible, simply that it had continued for so long without the prospect of victory, that he had no faith in the military commanders, ${ }^{5}$ or that he was worried about popular disaffection-but most likely it was the combination.

Lloyd George's criticism of the contemporary portrayal of the war as "a pretty picture ... with everybody doing gallant deeds" could equally have been levelled against much of the recruiting propaganda, which at the time was mainly in the form of posters and music hall songs. As an example, a British poster asked "Who can beat this plucky four?" above a painting of four soldiers who, according to their uniforms and the flags in their bayonets, represented England, Scotland, Wales and Ireland who looked valiant and in no danger of becoming bloody or muddy From a review of the over 200 English language posters-from the United Kingdom, the United States, Canada, India, Australia and Caribbean islands-available online, the desperation to recruit is evident, as is the message that subtlety was not a concern. One poster, from the South Midland Divisional Cyclist Company, asked "Are you fond of cycling? If not why not cycle for the King?" and at the bottom was the encouragagement "Bad teeth no bar" (IWM 1914-1916).

Likewise, music hall songs were often used as means for enhancing the war effort, for example "Men of England, You Have Got to Go!" and "Be a Soldier, Be a Man!" (Mullen 2015 , 154), though, of course, it was not a homogenous culture and to remain popular the venues primarily had to provide entertainment. However, of several hundred song titles I have seen from this period only one mentions "the Great War", and that was actually from 1919, "What did you do in the Great War, Daddy?" (172-173). The only poster I could find with the phrase is captioned "Daddy, what did YOU do in the Great War?" (IWM 1915), which was

${ }^{5}$ Lloyd George: "Haig does not care how many men he loses. He just squanders the lives of these boys. I mean to save some of them in the future. He seems to think they are his property", January $15^{\text {th }}$ 1917 (Taylor 1971, 139) 
presumably the source of the later song, and shows a suited man gazing pensively while his daughter asks the very question and his son plays with soldiers at his feet (IWM 1915).

The song reads as satirical, though the target is not clear from the lyrics. The characters include a woman who "sang to wounded Tommies" who lacked anaesthetic, and a 'special' who guarded a reservoir during the day to stop people drinking from it (Mullen 2015, 173). The post-war mockery of the slogan and underlying sentiment was likely written to appeal to resentment about this specific poster. According to its history at the Imperial War Museum, the poster publisher's director, Arthur Gunn, produced it out of contrition for not enlisting, it was mocked by soldiers and its designer, Savile Lumley, an illustrator of children's books, is thought later to have disowned it (Imperial 1915). It may well be symptomatic of, if not contributory to, incredulity that the war was in any positive sense great.

Another feature of the poster's use of "the Great War" is that it depicts a retrospective view from an imagined future, in English grammatical terms the way future perfect functions, looking back from a time to come. The way the phrase is couched is an indication of official inhibitions: despite other efforts which were more or less blackmail, they only felt secure calling the war "great" in terms of an unknown post-war era. It is notable that the periodical Punch frequently used this meme in a similar way. ${ }^{6}$ There were four references to "the great war" in 1914, the first in November; ten in 1915; five in 1916; fifteen in 1917; and fourteen in 1918, with five in December 1918, the most for any month, a semantic sigh of relief. Of these there were nineteen examples of the phrase used in connection with some form of hindsight from an indistinct time after the war, and two in December 1918 when that time had arrived, and so they were simply retrospective.

The nature of the publication meant that mostly the purpose was humorous, or what passed for humour in Punch at the time. Whether or not in allusion to the previously mentioned poster, often the theme was a play on asking someone what they had done in the Great War, seven times it was a father or grandfather who was asked, and five of those were in 1918. Indeed, the enquiry as a comedic device in the last year of the war shows a marked increase in cynicism and loss of faith in what the war stood for. In a poem, "Head-cover" a soldier anticipates what he will do if his son asks him "what mighty deeds/I've done in the Great War, I'll simply yank him over my knee/And soundly spank him" (Punch February 1918, 91, 1l. 34-36). In a series of short paragraphs apparently commenting on genuine news items is the presumably fictitious story of a baby named Grierson Plumer Haig French Smith-Dorrien, after six generals, so the father who served under them does not need to answer, "What did you do in the Great War, Daddy?"' (September 1918, 193)

If the two instances in the issues published after the Armistice show less of an acerbic attitude, at this distance the Christmas cracker style of levity reads as remarkably inappropriate for what the returning soldiers had just experienced. In one story about what ex-servicemen are proposing to do with their uniforms, Major Bounceby thinks it would be a good idea to put his on a mannequin which will be "in the corner of the drawing-room, as a constant reminder to Mrs. B. and the irreverent young B.'s of what papa did in the great war” (December 1918, 378). Another story is of Dixenham, who volunteers in order to have an answer if he is asked, "Daddy, what did you do in the Great War?" As he is 52 years old it is thought unlikely he will 
gain any military experience, but still he joins and only lasts for a week, until he is invalided out with lameness. However, his gardener is fit and so goes off to fight while Dixenham takes over gardening duties, which he believes is contributing to the war effort (December 1918, 410). The specific theme of men being answerable to their children for their war-time behaviour had only appeared twice before 1918, from which it could be inferred that when the situation was uncertain (which included an allied victory) the writers at Punch felt wary about being seen to undermine those who volunteered to fight, uncertain as to whether the British would consider the war great.

A recurring topic and basis for jokes was the shameful nature of men who did not do their bit, that their manhood was unquestionably lacking. A poem titled "V.M.B."7 is, from the subtitle, said to be a result of the previously mentioned propaganda: "What did you do, Daddy, in the Great War?' - Recruiting Poster". The narrator is worried about how he will be able to tell his children "The tale of how I helped my motherland" (July 1915, 58, 1. 6). It is a very hypothetical concern because he is not a father or a husband (1.3), but he nonetheless expresses his determination to stop his "stupid writing" (1. 9) and instead be "Devoted to the highexplosive kind" (1. 12). In the final stanza he considers the physical effects of writing to his person, as if they were war wounds, and thinks most will disappear (1.13-18). If this is parody with a target, presumably it is not soldiers at the front, and bearing in mind the nature of First World War literature in English, it would be ironic if poets as a whole were effectively being portrayed as incapable of military action and courage.

The attempt to find humour, however anaemic, through a narrator who compares his unexceptional activities to a soldier's was repeated two years later in a poem called "The General". In a dream a child asks what his grandfather, father and uncle did "'In the Great War long ago" (April 1917, 258, 11. 10-12). While the father was a soldier and the uncle a sailor, the (future) grandfather did household chores, including cooking, for various women who went out to work. The dénouement is that the child is so proud of his grandfather, the soi-disant general, that he "Stood at attention, stiff and mute/And gave his very best salute" (11. 59-60).

For the duration of the war the magazine used the phrase "the Great War" as a convenient method for really demeaning what must have been considered risible types, such as lower-paid office workers, the Irish and villagers. Fighting British soldiers never featured in this specific form of derision, though there are attempts throughout the four years at finding comedy in their experiences. One example is a cartoon of two wounded soldiers in which one says to the other, "'I tell yer, chum, there ain't never been a war like this one - not even in history"' (October 1918, 209). Therefore, jokes at the expense of soldiers in combat were not out of bounds, but in conjunction with "the Great War" it appears they would have been thought excessive or in bad taste, as if the phrase had a special elevated tenor, at least to the writers at Punch. This interpretation is not based solely on what could be argued to be a coincidental absence; it is wholly congruent with how "the Great War" was employed as a means to further diminish those seen as innately trivial.

\footnotetext{
${ }^{7}$ One definition of "vmb" is "Virgin Mary boy", to mean a boy or young man lacking in sexual experience, and although this may sound an unlikely explanation it is congruent with the implicitly self-deprecating depiction in the poem. (Urban)
} 
The most predictable object of this form of irony was the German military, though they were only lampooned in this specific way twice. In a poem called 'Truthful Willie' about a German prince whose "'constant aim was peace"" (Punch December 1914, 490, 1. 18), he is asked about Bernhardi who "who preached the Great War game"” (11.41-42), but the German denies knowledge of him and leaves, while his interlocutor is pleased "to have communed ... /With one so innocent" (11. 50-51). Frederich Adolf Julius von Bernhardi (1849-1930) was a Prussian general who was devoutly bellicose. As well as serving in the army, he wrote a series of books to promote the intrinsic worth of nations going to war, including Unsere Zukunft. Ein Mahnwort an das deutsche Volk [Our Future. A Word of Warning to the German People] just before the First World War. In it he asserted the need "to reclaim for war its moral justification", that it was "the highest expression of true culture, and as a political necessity in the interest of biological, social, and moral progress", and to avoid "inferior and degenerate races" conquering healthier ones "it becomes a biological necessity" (Bernhardi 1912). Therefore, having "the Great War" in an ironic text about peaceful Germans, and Bernhardi in particular, a few months after the outbreak of the war gives the phrase an unwelcome and aggressive tone, almost as though from a pacifist viewpoint: the desire for war characterises the Central Powers and is iniquitous and alien. In those circumstances, to consider it "Great" is indicative of their reprehensible natures.

Nearing the end of the war there is a story about the dangers British soldiers face when taking over old German positions, when the latter are in retreat, with the constant possibility of booby traps, "another reminder of the Great War" (October 1918, 227-228). At this point and in this context the phrase reads as virtually oxymoronic, that after the enormous toll the fighting has taken and when, according to an Allied perspective, the Germans should have accepted defeat, there is still surreptitious danger, which, from the same standpoint, proves the enemy to be ungallant and treacherous. Whatever the validity of the opinion, it is not surprising. However, the opprobrium heaped on Britons portrayed as lacking manly virtue because of not choosing to serve at the front, is more significant. In a meandering letter a soldier regrets having to remain in his staff offices while colleagues have gone to fight: "They were full of kindly commiseration about my future". While they will return "covered with glory and medals", all he can anticipate are "indelible ink-stains on my fingers and three vaccination marks on my left arm as my only mementoes of the Great War" (February 1915, 135). Despite the clear reluctance of his fellow soldiers to return to combat, its avoidance is the abnegation of a moral duty and the marks his secretarial experiences will leave expose the triviality of his contribution to the great undertaking.

In this Manichean paradigm, the antithesis to paper-shufflers were the Tommies, and as a bureaucrat held his manhood cheap so a combatant automatically merited deferential treatment. Other types also suffered in such comparisons. In a letter from an imagined immediate postwar future of 1925, soldiers are informed that they are to receive lessons in etiquette which includes lectures on deportment "given by civilians and actors who have been unable (through varicose veins or the necessity of amusing the soldier on leave) to take any part in the Great War" (July 1917, 70). In this dichotomy it is accepted that it is important to respect the experiences and persons of the men from the front and, whenever they run counter, to dismiss the attitudes of those who stayed behind, whether or not they had any choice. When a soldier is on leave and goes out in civilian clothes, he is first admonished by a woman whose husband 
is away fighting, and then "one urchin addressed him as 'Daddy' and asked him what he was doing in the Great War" (October 1917, 283).

The insularity that was mocked, that the woman cannot see beyond how much she is affected, and the boy asks the loaded question despite implicitly making no contribution himself, is accentuated by the grandiloquent use of "the Great War". Parochialism was similarly scorned by being placed in conjunction with the phrase, simultaneously diminishing those whose world ended a mile or two from where they stood, while enhancing the status of the war. A reporter from an East Anglian village after a Zeppelin attack noted that he had spoken "with the inhabitants [about] the Great War of which some of them had heard" (October 1915, 347). If fellow Britons who have just experienced an air-raid were thought appropriate subjects for ridicule, then it is no surprise that the Irish were not spared, if necessary through a piece of fiction. The story of "the Great War between Ballybun and Kilterash", "by the pellucid waters of that noble stream, the Bun, which hurls itself over a barrier of old tin-cans", relates that the reason and time it started are not known, but that it may have been because of the theft of a pig centuries before (February 1917, 112).

An irony at these efforts to make humour in this manner, depicting these villagers as too close-minded to see what was the one issue of genuine importance, is that the humourists are displaying their own narrow-mindedness. For them at the time, and to an obsessive degree, the First World War was the overriding and the only unquestionable concern. As a consequence, the further their contemporaries' interests were from the war the more they deserved ridicule. In a brief conversation in which a mother is teaching her children, she explains that "'the leaders of the Celtic Revival were famous for their literary achievement". When her son asks what they did in the Great War, their contribution to literature is made irrelevant, and the mother's reply confirms their superficial worth: “'they wrote beautiful poetry, and went out of doors only in the twilight"' (October 1918, 232). For this humour to have been effective, poetry, and that written by Irish poets in particular, needed to be seen as frivolous, and one had to accept that a contribution to the war effort was a connate obligation, especially if "the Great War", as opposed to "the war", was taken to be the correct description.

Others were said to be to blame for their failure to do their duty and for the same unforgiveable reason of writing. The writers at Punch could be free from censure doubtless because their ubiquitous topic, directly or obliquely, was the only one that counted. A review of a novel set in an English garrison town, mostly since 1914, notes the regret that it is "not greatly affected by the Great War" and should therefore "have been written, read and forgotten" (May 1918, 320). An invented book, in a list of anticipated superfluous publications, is called "'British Birds' by One Who Got Them", and he was "a slacker in the prime of life in the Great War" (January 1915, 65). "The Great War" looms large over their ornithology and town-life, and over the wilful failure to concentrate on it at the expense of everything else. However, even authors who wrote about and supported the war effort were not spared. A fictitious meeting is attended by H. G. Wells, the war is discussed and Wells leaves enigmatically before the end (December 1914, 515). The purpose of this story is hard to ascertain, beyond hoping that writers were thought to be inherently funny people, because many in Britain at the time, including those featured, had signed the "Authors' Declaration" a few months before in support 
of the British government's decision to go to war (Milne 2015). ${ }^{8}$ Indeed, one of those said to be in attendance was far more zealous about fighting Germany, and his warnings began a long time before 1914 .

William Le Queux ${ }^{9}$ was Anglo-French, initially a journalist, then a novelist, he also claimed to have been an amateur spy. Through his fairly extensive travelling he acquired the combination of ideas that Britain was wonderful and that neighbouring countries were envious of her successes and achievements. He was especially troubled by the Germans, who he thought had vindictive designs on his beloved country and its empire (Woods). For this cause, and despite the chance he would be seen as risible, Le Queux was relentless. His campaign began in 1893 with The Great War in England in 1897, the novel referred to in the Punch story mentioned above, and even if the magazine was hoping to ridicule the writer, by late 1914 he must have felt thoroughly vindicated (Panek 1981, 8). The story is of a Russian invasion which is helped by British ingenuousness, and includes a bomb attack on Edinburgh from a hot-air balloon (strikingly similar to H. G. Wells' The War in the Air from 1907, in which bombs are dropped from airships on New York ([1908] 2005). Ultimately Le Queux's invaders are defeated by a "pneumatic dynamite gun" (Panek 1981, 8).

Le Queux's industry and, almost certainly, creativity extended to warning those in power about German plots he had helped to uncover, including discussions in 1905 between the Kaiser and his military leaders about how they could conquer Britain, and Le Queux claimed to have seen images of the new weapons and maps. On another occasion he reported the existence of a list of members of the British government and some writers who, he was shocked to discover, were working as German spies. In both instances he regretted to tell the authorities that the documents had gone missing. The prime-minister, Henry Campbell-Bannerman, labelled him "a pernicious scare-monger" (Woods), but he was not dissuaded.

His most ambitious work was the novel The Invasion of 1910 (1906), which was not only a costly project, but an example of art by committee. Le Queux successfully appealed to Field Marshall Earl Roberts (1832-1914) for support in alerting the British authorities about German ambitions, and Roberts suggested that Le Queux should write a novel to warn the British people about the danger from Europe (Gannon 2005, 34-35). Naturally, the idea was attractive to Le Queux, but he wanted help. He asked Roberts for advice on military aspects of the novel, and the two went to East Anglia with the mind-set that they were Germans looking for the best way to invade London (Woods). Le Queux also had an influential advocate in the media who encouraged, financed and promoted the book.

${ }^{8}$ Among the 53 signatories alongside H. G. Wells were J. M. Barrie, G. K. Chesterton, Thomas Hardy, John Masefield and Sir Arthur Conan Doyle (Milne).

${ }^{9}$ William Tuffnel Le Queux (1864-1927) was born in London to an English mother and French father. He made unreliable claims about his education in Europe. From the 1890s he wrote fiction, short stories and novels (which averaged over five a year) and articles. Much of his fiction was set overseas, and involved the wealthy in crime (usually as the victims) or espionage. By 1898 he was being paid at the same rate as Thomas Hardy and H. G. Wells, but when his second wife sued him after their separation in 1910 he was declared bankrupt, probably due to a profligate lifestyle and failed business ventures. During World War One he wrote anti-German fiction as fact. In an obituary he was described as "a modern variant of Baron Münchausen" (Stearn 2004). 
In the first decade of the twentieth century Alfred Harmsworth, later known as Lord Northcliffe, ${ }^{10}$ owned the Daily Mail, the Daily Mirror, the Sunday Observer and (from 1908) The Times (Simkin 1997). Northcliffe told Le Queux not to worry about money and eagerly agreed to serialize the finished work. However, when he was shown the suggested invasion route, Northcliffe told them to change it so that the Daily Mail readership would have particular cause for alarm, and so for buying his newspaper. ${ }^{11}$ When the story appeared the newspaper sellers walked the streets dressed as German soldiers ("spiked helmets and Prussian uniforms") and it was a commercial success: the Daily Mail multiplied its readers and the novel sold a million copies in 27 languages (Woods).

There was another contributor to The Invasion of 1910. A chapter is about naval incidents and it was written by H. W. Wilson, considered an expert in the field. Herbert Wrigley Wilson ${ }^{12}$ worked, until the start of the First World War, as a leader writer and deputy editor at the Daily Mail (Clarke 436-437), then in August 1914 Northcliffe made him editor of a new magazine: ${ }^{13}$ The Great War: The Standard History of the World-Wide Conflict (Wilson 1914-1918). Northcliffe's hope was that a publication with photographs, maps and quite detailed information of the conduct of the war by both sides would engage the public and goad young men into volunteering. He had already used his Amalgamated Press to campaign for a stronger military and against what he saw as an aged and incapable cabinet during the Boer War. From 1914 to 1916 his newspapers published criticisms, for example, of the failures of munitions and of Field Marshall Kitchener's tactics (Boyce 2004). In the First World War the Daily Mail had articles intended for soldiers, occasionally written by soldiers, and 10,000 copies were delivered to the front every day (Thompson 1999, 147). Northcliffe had warned and lobbied politicians to prepare for war to the extent that some claimed he came second only to the Kaiser as the principle cause (Boyce 2004). However, he clearly wanted the enemy to be blamed. On August $3^{\text {rd }} 1914$ the Daily Mail's front page read, "The Great War Begun by Germany", a headline he must have relished (Thompson 1999, 24).

The phrase "the Great War" clearly benefitted the proponents of war like Northcliffe and Le Queux. In anticipation of and during the conflict they could use it in the hope of emphasizing the magnitude of their fears, whether sincere or exaggerated, and the momentous nature of the

${ }^{10}$ Alfred Charles William Harmsworth, Viscount Northcliffe (1865-1922), became a reporter at 15 and founded his own newspaper firm in 1888 which became Amalgamated Press Company. He wanted his newspapers to be more accessible, so they had less text, more pictures and striking headlines. He founded the Daily Mail in 1896 and the Daily Mirror, with an all-female staff, in 1903. He expressed unabashedly patriotic views and the value of a strong military through his newspapers, and he had significant political influence. Having warned of the German threat before 1914, he exposed British tactical and armament shortcomings, and funded a postal service so that soldiers could send letters home. He believed that in peace Germany should be punished financially (Boyce 2004).

${ }^{11}$ Maps were included with the serialization so that readers could have a more accurate idea of their proximity to the threat (Panek 8 ).

${ }^{12}$ Herbert Wrigley Wilson (1866-1940) was considered an authority on the navy and wrote on the subject so that the British people would want the Royal Navy to remain dominant. He worked as a journalist, wrote several books on the military and became attached to Northcliffe and his media empire, employed in various positions. Before World War One he warned of the German increase in armaments (Morris 2004).

${ }^{13}$ From images of the covers Wilson was often credited as sole editor, but had been assisted by John Alexander Hammerton, acknowledged later. 
war they protested Britain was bound to fight. In its early stages Lloyd George echoed this certainty of the justice and moral imperative of the call to arms, but his overt change in attitude around the time he became prime-minister, coincidentally or not, suggests a definite growing antipathy among the British public. For his predecessor, Asquith, his public misgivings suggest he was never entirely confident of the electorate's approval despite his private celebration that he had been in charge when war was declared. The attempts the writers at Punch made to extract humour from their various uses of "the Great War" certainly show vacillations, as some have noted (as, for example, MacCallum-Stewart), as if, like Asquith, their constant concern was not to offend public sensibilities, and they could never be sure of the people's current mood. This reticence is evident in the nature of most of the humour that included the phrase, a squeamish manner of deriding types and behaviour without having the backbone to extol a war they favoured.

Bibliography

AMAZON UK “Great War” book search. Accessed on November 2015 at http://www.amazon.co.uk/s/ref=sr_pg 10? rh=n\%3A266239\%2Ck\%3A\%22great+war\%22\& page $=10 \&$ keywords $=\% 22$ great + war $\% 22 \& i e=U T F 8 \& q i d=1447534280$ 
BERNHARDI, Genreral Friederich von, 1912._Unsere Zukunft. Ein Mahnwort an das deutsche Volk [Our Future. A Word of Warning to the German People]. Translated by Thomas

Dunlap. Stuttgart, Berlin. Accessed November 2015 online at http://germanhistorydocs.ghidc.org/pdf/eng/522_Inevitability\%20of\%20War_103.pdf

Bingham, Adrian, 2013. "'The Paper that Foretold the War': The Daily Mail and the First World War". Sheffield: Cengage Learning, 2013. Accessed online at http://gdc.gale.com/assets/files/daily_mail/the paper_that_foretold the war.pdf

BoyCE, D. George, 2004. “Alfred Charles William Harmsworth biography”, Oxford Dictionary of National Biography. Oxford: Oxford University Press. Accessed online at http://www.oxforddnb.com/view/article/33717?docPos=1

Brock, Michael, edited, 1992. H. H. Asquith, Letters to Venetia Stanley. Oxford: Oxford University Press.

Bunbury, Sir Henry, 1854. Narratives in Some Passages from the Great War with France, from 1799 to 1810. London: Richard Bentley.

Clarke, Ignatius Frederick, 1997. The Great War with Germany, 1890-1914: Fictions and Fantasies of the War-to-come. Liverpool: Liverpool University Press.

ForTeSCUE, J. W., 1911. British Statesmen of the Great War: 1793-1814. Oxford: Clarendon Press.

GANNON, Charles E., 2005. Rumors of War and Infernal Machines. Lanham, Maryland: First Rowman and Littlefield.

HANSARD transcript, June $11^{\text {th }} 1917$. Accessed online at http://hansard.millbanksystems.com/commons/1917/jun/11/death-of-major-redmondmp\#S5CV0094P0_19170611_HOC_301

HOLMAN, Brett, 2009. "The invasion of The Invasion of 1910". Accessed online at http://airminded.org/2009/10/04/the-invasion-of-the-invasion-of-1910/

IMPERIAL War Museum, 1914-1916. "Are you fond of cycling?” poster. Accessed online at http://www.iwm.org.uk/collections/item/object/28301

— 1915-1916. "Who can beat this plucky four?" poster. Accessed online at http://www.iwm.org.uk/collections/item/object/31631

— 1915. "Daddy, what did you do in the Great War?" poster. Accessed online at http://www.iwm.org.uk/collections/item/object/17053

LEE, Stuart. "The War, the Great War and the First World War". Accessed October 2015 online at http://ww1centenary.oucs.ox.ac.uk/memoryofwar/the-war-the-great-war-the-firstworld-war/ 
MacCallum-Stewart, Esther, 2009. "Satirical Magazines of the First World War: Punch and the Wipers Times". Accessed online at http://www.firstworldwar.com/features/satirical.htm

MANCHESTER, William, 1983. The Last Lion: Winston Spencer Churchill, 1874-1932. Boston: Little, Brown.

Matthew, H. C. G., 2004. “'Asquith, Herbert Henry, first earl of Oxford and Asquith (18521928)". Oxford Dictionary of National Biography. Oxford: Oxford University Press, Accessed online at http://www.oxforddnb.com/view/article/30483

MiLne, Nick, 2015. "Pen and Sword Pt. I: The Authors' Declaration”. Accessed online at http://ww1centenary.oucs.ox.ac.uk/unconventionalsoldiers/propaganda-the-authorsdeclaration

Morgan, Kenneth O., 2004. "George, David Lloyd, first Earl Lloyd-George of Dwyfor (1863-1945)". Oxford Dictionary of National Biography, Oxford: Oxford University Press. Accessed online at http://www.oxforddnb.com/view/article/34570

Morris, A. J. A., 2004. "Wilson, Herbert Wrigley (1866-1940)". Oxford Dictionary of National Biography. Oxford: Oxford University Press. Accessed online at http://www.oxforddnb.com/view/article/36958

MosLey, Nicholas, 2002. "He never wrote back to his sons". Review of The Asquiths by Colin Grifford, The Telegraph, October $12^{\text {th }}$. Accessed online at http://www.telegraph.co.uk/culture/4728970/He-never-wrote-back-to-his-sons.html

Mullen, Dr. John, 2015. The Show Must Go On! Popular Song in Britain During the First World War. Farnham, Surrey: Ashgate Publishing.

PANEK, LeRoy, 1981. The Special Branch: The British Spy Novel, 1890-1980. Bowling Green, Ohio: Bowling Green University Popular Press.

SEAman, Owen, edited, 1914-1918. Punch Magazine, vol. 147-155. London: Punch Publications. Accessed online at http://onlinebooks.library.upenn.edu/webbin/serial?id=punch

SIMKIN, John, 1997, revised 2015. "Alfred Harmsworth, Lord Northcliffe”. Accessed online at http://spartacus-educational.com/BUharmsworth.htm

SiMPSON, J. A. and E. S. C. Weiner, prepared, 1991. The Compact Oxford English Dictionary, second edition. Oxford: Clarendon Press.

STEARN, Roger T., 2004. “Le Queux, William Tufnell (1864-1927)”. Oxford Dictionary of National Biography, Oxford: Oxford University Press. Accessed online at http://www.oxforddnb.com/view/article/37666

TAYLOR, A. J. P., edited, 1971. Lloyd George: A Diary. London: Hutchinson.

— , 1992. English History: 1914-1945. Oxford: Oxford University Press. 
Thompson, J. Lee, 1999. Politicians, the Press and Propaganda: Lord Northcliffe and the Great War, 1914-19. Kent, Ohio: Kent State University Press.

Treble, Patricia, 2014. “Maclean's named the Great War". August $2^{\text {nd }}$, Maclean's. Accessed online at http://www.macleans.ca/authors/patricia-treble/the-start-of-the-great-war/

"VMB" definition, Urban Dictionary. Accessed November 2015 online at http://www.urbandictionary.com/define.php?term=VMB

WAR SPEECHES by British Ministers: 1914-1916. 1917. London: T. Fisher Unwin.

Wells, H.G., [1908] 2005. The War in the Air. London: Penguin Classics.

WILSON, H. W. and J. A. Hammerton, 1914-1918. The Great War: The Standard History of the World-Wide Conflict. London: Amalgamated Press.

— The Great War magazine, issue no. 1, August 1914. Image accessed online at http://www.archivecdbooks.ie/acatalog/World_War_1.html

— The Great War magazine, issue no. 172, June 1917. Image accessed online at http://www.websterbookstore.com/si/1834483.html

WILSON, Trevor, edited, 1970. The Political Diaries of C. P. Scott, 1911-1928. London: Collins.

— 2011. The Downfall of the Liberal Party, 1914-1935. London: Faber \& Faber.

Woods, Brett F., "War, propaganda, and the fiction of William Le Queux". Accessed

November 2015 online at http://critique-magazine.com/article/lequeux.html 